\title{
GLL
}

Geomatics, Landmanagement and Landscape No. 1 • 2020, 153-162

\section{SMART CITY KRAKÓW IN THE HISTORICALLY CONDITIONED ENVIRONMENT}

\author{
Bogdan Jankowicz
}

\begin{abstract}
Summary
Creating a smart city is a long-term process related to planning a new urban structure, whereas knowledge of the history of the city's and its area's development is not without significance. The presented article shows how environmental factors that may have their sources in the past may impact the contemporary creation of a smart city. When planning the development of a smart city, it is impossible not to take into account the history of the city's development in the past and the environment in which it was created. Changes in Kraków's environment (the terrain, land forms, and water network) that have occurred over many years have undoubtedly a significant impact on the formation of a specific city profile - not only in terms of geography and climate (humidity, poor ventilation) but also in social, communication and cultural terms. These factors mean that the creation of smart-city in the case of Kraków will have to be slightly different than in the case of other cities with an environment that has been more stable over time. Apart from the lack of financial resources, the development of a smart city in Kraków is hampered by the lack of implemented solutions that would involve the local community in the co-management of the city. In addition, the Open Data concept, which allows public data to be opened and made available to residents in various digital formats, encouraging the creation of new services based thereon, still remains an untapped resource. Some cities, such as Wrocław, Poznań or Łódź have tried to make available some of the city's data, albeit to a very small extent. Another problem is the lack of spatial planning and urban chaos. Reducing energy consumption and carbon dioxide emissions is also a substantial challenge facing the local authorities. A majority of large Polish cities, especially in winter, exceed the permissible air pollution standards, which automatically excludes them from the group of smart cities.
\end{abstract}

Keywords

smart city • technologies $\bullet$ environmental conditions

\section{Introduction}

The construction of a smart city is the implementation of a specific action strategy, and its expression lies in the implemented projects that allow the improvement of urban systems, based on advanced technologies, which in the long term can bring measurable economic and social benefits. When planning the development of a smart 
city, it is impossible not to take into account the history of the city's development in the past, as well as the environment in which it was created. Changes in the terrain and landforms of Kraków, from pre-location times to today, are enormous, and thus they have a significant impact on the climate, and on the life of the city's inhabitants. Their causes are mainly the result of residents' aspirations to secure a suitable place of living, and relative comfort of life. Apart from the few elevations, the area of Kraków is relatively flat and low in relation to the existing hydrographic network. Hence the numerous floods throughout the city's history. Residents of the city, who have settled in these areas, always fought with the dangerous element of water. Therefore, they built embankments, levees, dams, and regulated rivers to adapt the area to their needs. This continued for hundreds of years and led to specific changes in the terrain. The city's characteristic location - within the distinctive land depression - has also contributed to numerous changes in the terrain of Kraków.

\section{Historical conditions of Kraków's environment}

As evidenced by excavation works, Kraków was built on a small hill among wetlands. The nature of Kraków's terrain and landforms was mainly determined by the geological structure of the subsoil and the resistance of the rocks found here to external destructive factors.

Within the area of today's Kraków agglomeration, significant changes in the terrain have been introduced for centuries of human stay and activity. Basically, they went in the direction of levelling the terrain, leading above all to raising its level in locations of land depression, through the growth of waste and rubbish layers, as well as by deliberate soil filling. These changes were also marked by the reduction of inconvenient elevations to level the surface, and less often by introducing artificial embankments raising the area (levees, some locations in Wawel hill). The levelling activity of man was the strongest in the densely inhabited parts of Kraków, and weakened as it moved away from the centres of urban life towards suburban, especially rural areas. In the distant times, this activity was weaker, gaining strength over the centuries, up to the greatest changes in the present time.

In the earliest development of Kraków we observe two opposite trends:

1) development of northern areas in the Pogórze Prądnickie (Prądnik Foothills; (215 $\mathrm{m}$ a.s.l.) excluding defensive considerations,

2) edging into the Wisła (Vistula) floodplain (205 $\mathrm{m}$ a.s.l.), excluding many economic advantages, however, including defensive considerations.

The oldest spatial arrangement of Kraków formed along the north-south axis from Krzemionki to the hills of Prąnik. Defensive reasons decided, however, that the city limits narrowed towards the water catchment area of the Wisła (Vistula), Rudawa, and Prądnik rivers. This determined the historical development of the city and led to the situation in which the main difficulties for today's urban planner include: 
- avoiding the consequences of an unhealthy climate,

- avoiding the impact of subterranean waters,

- densely concentrated built environment of the city.

In the past, these inconveniences were accepted for defensive reasons. Over the centuries, there has generally been significant impoverishment to the city's hydrographic network. Numerous riverbeds, ponds, beards, moats, backwaters and swamps have disappeared. This area was almost completely drained (Fig. 1).

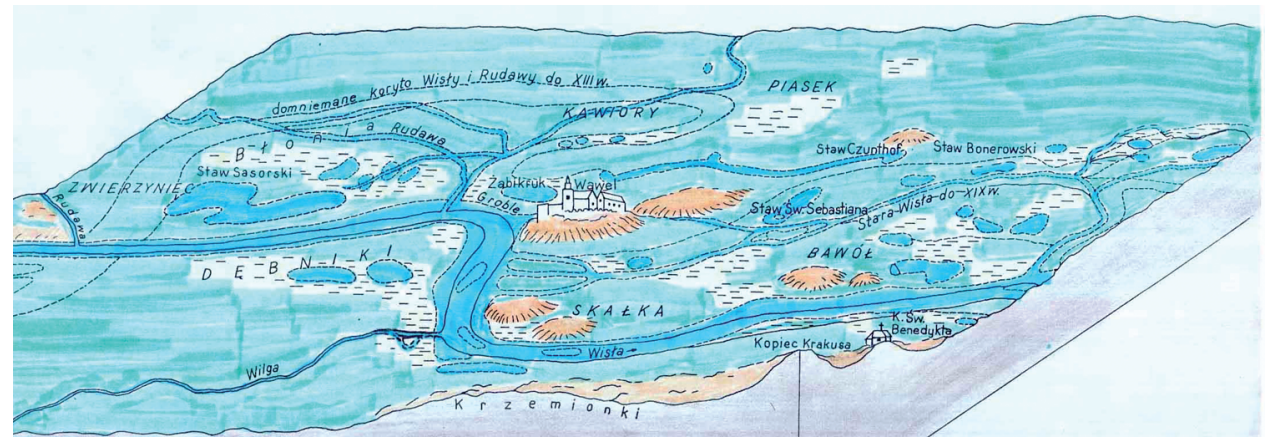

Source: developed by the Author

Fig. 1. Past terrain forms of historical Kraków with the hydrographic network

As can be observed from Figure 1, the land occupied by the water network in Kraków in the area under consideration decreased from 116.20 ha (13.6\%) from pre-location times to 44.86 ha $(5.2 \%)$ currently, which signifies an almost threefold decrease in hydrographic network. Taking into account the temporary existence of Staw Kazimierski (Kazimierz Pond) and Jezioro Jelitowskie (Jelitowskie Lake), the water area has decreased from 132.90 ha (15.5\% of the total area) to 44.86 ha $(5.2 \%)$ as of today, not counting wetlands, boggy areas and areas which are periodically flooded. 100 ha of swamps were liquidated, which represents $11.7 \%$ of the area under consideration [Jankowicz 1993].

Changes in Kraków over many centuries have a significant impact on the current environmental situation of the city, and being aware of those processes should contribute to the proper, further development of urban agglomeration. It should be emphasized that such a substantial urban, economic and cultural development of Kraków would not have been possible were it not for the changes in the terrain, and in particular the hydrographic network in this area, caused largely by the activities of the inhabitants. Hence the special significance of these changes for the future of the city, which is the cradle of Polish culture, art and architecture. 
Table 1. Quantitative changes in the hydrographic network of Kraków in the studied area (855 ha)

\begin{tabular}{|c|c|c|c|}
\hline \multirow{2}{*}{ Hydrographic network } & \multicolumn{2}{|c|}{ Area [ha] } & \multirow{2}{*}{ Remarks } \\
\hline & In the past & At present & \\
\hline Rivers: & 90.88 & 44.86 & - \\
\hline $\begin{array}{l}\text { Wisła (including "Stara } \\
\text { Wisła") }\end{array}$ & 73.50 & 43.20 & $\begin{array}{l}\text { Currently "Stara Wisła" (the Old } \\
\text { Wisła) does not exist }\end{array}$ \\
\hline $\begin{array}{l}\text { Rudawa (including } \\
\text { Nieciecza and millraces) }\end{array}$ & 15.44 & 1.04 & $\begin{array}{l}\text { Currently millraces and Nieciecza } \\
\text { do not exist }\end{array}$ \\
\hline Wilga & 1.00 & 0.62 & - \\
\hline Prądnik & 0.94 & - & - \\
\hline Moat & 3.32 & - & - \\
\hline \multicolumn{4}{|l|}{ Ponds: } \\
\hline Sasorski & $22.00(38.7)$ & - & - \\
\hline "Na Stawach" & 4.50 & - & - \\
\hline Żabikruk & 1.50 & - & - \\
\hline Jezioro Jelitowskie & $2.10(5.0)$ & - & $\begin{array}{l}\text { Temporarily XVIII to XIX century } \\
\text { much larger }\end{array}$ \\
\hline św. Sebastiana & 3.00 & - & - \\
\hline Bonerowski & 1.00 & - & - \\
\hline $\begin{array}{l}\text { Ponds at the influx of } \\
\text { Prądnik }\end{array}$ & 1.50 & - & - \\
\hline $\begin{array}{l}\text { Five ponds in the vicinity } \\
\text { of Jewish Cemetery }\end{array}$ & 5.70 & & \\
\hline Staw Kazimierski & $1.20(15.0)$ & - & $\begin{array}{l}\text { Temporarily to } 2 \text { nd half of XVII } \\
\text { century much larger }\end{array}$ \\
\hline \multicolumn{4}{|l|}{ Hydrographic network } \\
\hline total & $116.20(132.9)$ & 44.86 & \\
\hline and as percentage & $13.6 \%(15.3 \%)$ & $5.2 \%$ & \\
\hline
\end{tabular}

\section{Smart city in the theory of city development}

Certainly, classic urban development factors are well recognized and described. However, in recent decades, new development factors have been included among key concepts of city transformation, such as competitiveness, entrepreneurship, innovation 
and talent. At the same time, theories regarding the economy of urban resources were developed, e.g. smart growth, the essence of which is planning in the city that allows reducing costs resulting from uncontrolled urban sprawl [Sikora-Fernandez 2016].

By $2050,70 \%$ of the world population will live in cities. Cities represent more than $50 \%$ of global GDP and 70\% of total energy consumption. A billion people have moved into the city since 2000 [Ferrer 2017].

The development of advanced technologies and the emergence of creative industries, which have their sources in the science and culture sector, make modern cities powerful systems in which the challenge is to optimize the use of resources and prevent negative external impacts. Therefore, the use of advanced technologies in the development of the city becomes necessary to improve the quality of life as well as living conditions of all urban users [Taylor 2015].

The theory of urban development distinguishes several concepts relating to innovation, creativity and advanced technologies [Neirotti 2014]. A knowledge-based city focused its development factors around education, intellectual capital and a high level of innovation. The digital city used communication and information technologies (ICT), whereas the development of the creative city was based on capital co-developed by the most creative individuals with simultaneous high efficiency in local government management [Somayya and Ramaswamy 2015].

In recent years, the concept of smart city has developed in the literature on the subject. Essentially, it combines several ideas about urban development factors. In the documents of the European Union, this concept is linked with activities aimed at improving the environment, in particular the reduction of carbon dioxide emissions into the atmosphere and effective energy management [Strategic Energy Techno-Logy Plan 2007]. Smart solutions also appear in relation to the role of urban transport and digitalised (online access) public administration. However, there is no single, unambiguous definition of a smart city - this concept is interpreted differently, and many researchers who deal with the subject tend to emphasize various aspects. A smart city is a territory with high learning and innovation capacity, having advanced technologies and high management efficiency, able to attract and retain high-class specialists, as well as having well-developed transport and telecommunications infrastructure, ensuring high quality of life for residents through infrastructure investment projects, creation and distribution of wealth, and conducting activities related to poverty reduction and social exclusion [Nam and Pardo 2017].

And so, the discourse around smart city emphasizes the role of advanced technologies in its functioning. Nevertheless, it is not only technologies that are the catalyst factor in the city's development processes - it is also important to manage in such a way as to economise and conserve all city resources. Given that the public sector has undergone a number of contextual changes in recent years, and the development of the information society, digital technologies and knowledge-based economy has forced public administration to change the terms of service provision - management using the smart city concept has become a requirement for local authorities making decisions on the directions that urban development should take. The change in the manner 
of providing these services takes place in six dimensions - system areas of the city's functioning, such as: the economy, mobility (in traditional terms - transportation, in contemporary terms - communication), environment, quality of life, joint governance and people [Urbnews.pl].

In Poland, only two cities qualified to enter the first hundred of the IESE Cities in Motion Index 2017 report - the list of the most smart cities throughout the world. Warsaw is 54th in the ranking, whereas Wrocław is 95th. New York, London and Paris are the leaders. Smart city is the concept, which assumes that the city uses advanced technologies in order to improve the quality of life, in all areas of functioning. The idea is for the inhabitants to live better, and at the same time to reduce the costs of operating the entire city. The IESE Cities in Motion Index 2017 report analyses all aspects of the quality of life in 180 cities around the world [Rzeczpospolita 8.11.2017].

Apart from the lack of financial resources, the development of a smart city in Kraków is hampered by the lack of implemented solutions that would serve to involve the local community in co-management of the city. Delegating decisions to residents or initiative groups is still not very popular among local authorities. Public consultations, often organized during office hours, are of interest to a small group of people only. The so-called "civic budget" alone, already in use in many Polish cities, is still not enough to talk about smart co-governance. Furthermore, the Open Data concept, which allows public data to be opened and made available to residents in various digital formats, encouraging the creation of new services based on them, is still virtually unused in Poland. Some cities, such as Wrocław, Poznań or Łódź try to share some of the city's data, but this is done to a very limited extent. Another problem is the lack of spatial planning and urban chaos in cities (some areas of Kraków, e.g. Azory district, long after 2010 did not have a spatial development plan!). Reducing energy consumption and carbon dioxide emissions is also a significant challenge for local authorities. Most large Polish cities, especially in winter, exceed the permissible air pollution standards, and that automatically excludes them from the group of smart cities.

To sum up, it is assumed that cities can be defined as smart if they have the following smart components:

1. Economy (smart economy) - measured by the city's entrepreneurship and productivity, adaptation to changes, flexibility of the labour market and international cooperation, as well as ensuring control of the balance between the demand and supply of goods and services.

2. Mobility (smart mobility) - measured by the availability of information and communication infrastructure, through the development of sustainable, innovative, safe and relatively cheap transport (encouraging citizens to use public transport rather than their own vehicles).

In this instance, the author of the article additionally proposes smart traffic management: the so-called "green line", determining the smoothness of traffic by displaying the suggested speed; extending the yellow light (when changing from red to green) to at least 0.75 seconds, which will prevent inertia in moving away from the lights; smart parking lots, where information is displayed on special boards at the entrance 
to the parking lot about free parking spots and their location, so that the driver does not wander around the parking lot; mandatory lighting of pedestrian crossings and improving their visibility from the driver's point of view. In addition, individual electro-mobility - a very important factor, especially in the city and the surrounding area - the problem here is not so much the relatively short range of electric cars (in the city, it is of secondary importance due to short distance journeys), but the relatively long battery charging time (sometimes it takes several hours compared to a few minutes spent refuelling a car with traditional fuel or hydrogen). Currently, the most commonly used electric car chargers have a power of $50 \mathrm{~kW}$, whereas in order to temporarily approach the time of traditional refuelling they would have to have at least ten times more power (e.g. $500 \mathrm{~kW}$ ). However, which battery would withstand such electricity, and would the city network with more cars withstand such a load? In this author's opinion, this is a temporary solution, while the future belongs to electric cars powered by fuel cells, e.g. hydrogen (currently Toyota is one of the pioneers of this type of drive, with its Mirai model). Poland is the fifth or sixth producer of hydrogen in the world - if this hydrogen could be converted into pure hydrogen, about 6 million hydrogen cars could be supplied annually; and hydrogen is definitely an alternative fuel of the zero-emission future [dziennik.pl].

3. The environment (smart environment) - measured by the attractiveness of the natural environment, the level of pollution, environmental protection provisions, and through resource management methods - having in mind the environmental conditions of the city, which are the result of centuries-old human-led changes. An interesting idea may be parks - gardens designed according to the Haussmann idea, integrated into the city structure [Baster 2010].

The author also proposes smart segregation of garbage, as the current system is rather unclear, not all residents comply with it, and it is highly time-consuming, for both residents and the garbage service.

4. People (smart people) - characterized by the level of their qualifications; lifelong learning; social and ethnic diversity; creativity; openness and participation in public life not only through modern media, expanding the knowledge and broad-mindedness of residents, but also through direct contacts; easier and more common "digital literacy" of residents.

5. Living (smart living) - measured by more easily accessible existing and new cultural facilities; living conditions (health, safety, housing); educational facilities; tourist attractiveness, including the attractiveness of "post-communist" housing estates, which are not lacking in Kraków, as opposed to introducing further "concrete" developments as it has been done so far; and so-called social cohesion. An interesting application can be the introduction to parks and squares of the so-called solar benches, enabling the use of the internet, USB charging, and so forth, powered by solar energy.

6. Smart governance - expressed in the transparency of city management; social/ public participation; the quality of public services; and the successful implementation of the municipal development strategy. 
In this regard, the author proposes - to increase the financial participation of investors (developers) of new buildings and housing estates in the construction of road infrastructure (roads, pavements, parking lots, bicycle paths, introduction of clearer, smart signage). Currently, buildings and housing estates are being built in Kraków with unchanged communication (road) infrastructure.

Barcelona can be a good benchmark an example for Kraków to follow, being the first in the hierarchy of smart cities in Spain and the fourth in Europe. The city is part of the metropolitan area, which consists of 36 municipalities with a total area of 633 $\mathrm{km}^{2}$ and a population of over 3.2 million. It is the sixth largest metropolitan region in the European Union [Barcelona Visio... 2010].

A CITY OS platform was created in Barcelona, which is a tool for processing and analysing data and urban events. As a result, the platform allows for simulation and prediction of any problems that may arise in the city. The platform is designed to integrate and correlate city data from measuring devices, databases and social networking sites, as well as to prepare analyses, simulations and forecasts based on the collected data. Data management within the platform takes place simultaneously in a horizontal organization so as to transfer information between specific usage applications, and in a vertical organization - between different city monitoring and crisis management centres.

For quick customer service, procedures based on telematics processes have been developed and implemented. Noteworthy in this area is the Open Data application, which allows municipalities to open public data and make them available in digital and standard formats. This in turn allows the data to be reprocessed by residents, and is an encouragement to create new services based on that data, whether paid or free - by private entities complementing public services. The Open Data concept is an indispensable element of the "open government" and the idea of "government as a platform" [Sobczak 2014].

One of the most developed projects is the one related to electric cars (vehículos eléctricos). In addition, most city buses and a significant proportion of taxis are electric vehicles. This type of transport is energy efficient and emits less pollution to the environment. It should be mentioned that Barcelona has 300 devices in various parts of the city that allow you to charge the battery without paying any fees.

It is worth mentioning other interesting projects such as:

- smart intersections - equipped with devices to help blind people cross the street, while reducing the nuisance caused by noise generated by these devices;

- a smart system that manages the change of lights in crisis situations, enabling municipal services to chart the optimal, fastest itinerary to an event;

- a project related to water resource management, based on automated irrigation systems and remote control of irrigation and fountains. The system implemented in city parks optimizes the consumption of water from the municipal network using a series of sensors located in lawns. The system calculates the amount of water introduced into the ground from the municipal network in relation to the water needs of 
plants and supplements this data with information on precipitation depending on evaporation, filtration and water runoff. Irrigation stops automatically when there is precipitation, and if it is windy, it regulates the water flow so that it does not fall outside the irrigation area.

\section{Conclusions}

The development of ICT techniques, allowing for fast, unlimited data transmission, database availability, the emergence of an effective and easily programmable infrastructure, and an expanded network of sensors make cities more and more computerised. This requires a change in the way the city is managed as a result of the use of advanced technologies. The main advantage is the improvement of the quality of services provided to city users and savings of financial outlays, time and energy from the point of view of the city's functioning.

\section{References}

Baster P. 2010. Parki francuskich projektantów - współrealizatorów idei Haussmanna. Architektura. Czasopismo Techniczne, 13(107), 5-A. Wydawnictwo Politechniki Krakowskiej.

Ferrer J.R. 2017. Field Actions Science Reports, Barcelona’s Smart City vision: An opportunity for transformation. Institut Veolia. http://journals.openedition.org/factsreports/4367

Jankowicz B. 1993. Uwarunkowania historyczne środowiska Krakowa. Aura, 11.

Nam T., Pardo Th.A. 2017. Center for Technology in Government. University at Albany, State University of New York, U.S. Smart City as Urban Innovation: Focusing on Management, Policy, and Context. Proceedings of the 5th International Conference.

Neirotti P. 2014. Current trends in Smart City initiatives: Some stylised facts. Elsevier Cities, 38, June, 25-36.

Shelton T., Zook M., Wiig A. 2015. The 'actually existing smart city'. Cambridge Journal of Regions, Economy and Society, 8, 13-25. DOI: 10.1093/cjres/rsu026

Sikora-Fernandez D. 2016. Praktyczne aspekty budowy smart city na przykładzie Barcelony (Practical aspects of smart city development on the example of Barcelona). Prace Naukowe Uniwersytetu Ekonomicznego we Wrocławiu, 432.

Sobczak A. 2014. Miasto jako platforma - fundament Smart City. http://inteligentnemiasta.pl/ miasto-jako-platforma-fundament-koncepcji-smart-city/5239/ [accessed: 25.08.2015].

Somayya Madakam, Ramaswamy Ramachandran. 2015. Barcelona Smart City: The Heaven on Earth. Internet of Things: Technological God. https://www.researchgate.net/publication/292906873_Barcelona_Smart_City_The_Heaven_on_Earth_Internet_of_Things_ Technological_God.

Strategic Energy Technology Plan (SET Plan). 2007. http://eur-lex.europa.eu/legal-content/EN/ TXT/?uri=URISERV:127079 [assessed: 17.11.2015].

Dziennik.pl, 12.10.2019.

Rzeczpospolita, 8.11.2017

Urbnews.pl 
Dr inż. Bogdan Jankowicz

Uniwersytet Rolniczy w Krakowie

Katedra Geodezji Rolnej, Katastru i Fotogrametrii

ul. Balicka 253a, 30-198 Kraków

e-mail: rmjankow@cyf-kr.edu.pl

ORCID: 0000-0003-1603-0864 